\title{
Pemanfaatan sampah organik sebagai media pakan larva Tenebrio molitor (ulat hongkong)
}

\author{
Asri Nur Azizah ${ }^{*}$, Pranoto $^{2}$, MTh Sri Budiastuti ${ }^{3}$ \\ Program Studi Magister Ilmu Lingkungan, Universitas Sebelas Maret Surakarta \\ J1. Ir Sutami-Surakarta, 57126 \\ 1 asriana@student.uns.ac.id*; ${ }^{2}$ pakpranotomipa@staff.uns.ac.id; 33 budiastutiw@yahoo.com \\ *korespondensi penulis
}

\begin{abstract}
Abstrak
Sampah organik dapat memberikan dampak negatif bagi lingkungan apabila tidak dilakukan pengelolaan maupun pengolahan yang baik. Pemanfaatan sampah organik sebagai pakan larva Tenebrio molitor (ulat hongkong) merupakan salah satu cara mengelola sampah organik. Penelitian ini bertujuan untuk mengetahui adanya pengaruh dari jenis sampah organik yang diberikan dengan dosis yang berbeda terhadap pertumbuhan larva Tenebrio molitor dengan parameter panjang tubuh, pertambahan berat tubuh, serta mortalitas. Metode yang digunakan adalah metode eksperimen dengan Rancangan Acak Lengkap (RAL). Penelitian menggunakan 6 perlakuan dengan 2 kali ulangan. Sampah yang digunakan adalah sampah sayur dan buah serta kotoran ayam dengan masing-masing sampah diberikan dosis sebesar 12,5 mg/larva/hari, $25 \mathrm{mg} / \mathrm{larva} /$ hari, dan 50 $\mathrm{mg} / \mathrm{larva} / \mathrm{hari}$. Variabel yang diamati adalah pertumbuhan larva Tenebrio molitor dengan parameter panjang tubuh, berat tubuh, dan mortalitas (kematian). Hasil penelitian menunjukkan bahwa rata-rata panjang tubuh dan pertambahan berat tubuh larva tertinggi adalah pada media pakan kotoran ayam dengan dosis $25 \mathrm{mg} /$ larva/hari, yaitu sebesar $2,021 \mathrm{~cm}$ dan 0,067 gram. Rata-rata tingkat mortalitas tertinggi adalah pada media sampah sayur dan buah dengan dosis $50 \mathrm{mg} / \mathrm{larva} /$ hari dengan persentase $12,8 \%$.
\end{abstract}

Kata kunci: sampah sayur dan buah, kotoran ayam, pertumbuhan, larva Tenebrio molitor

\begin{abstract}
Organic waste can have a negative impact on the environment if there is no good management or processing. Utilizing organic waste as larvae feed Tenebrio molitor (hongkong caterpillar) is one way to manage organic waste. This study aims to determine the effect of the type of organic waste given at different doses on the growth of Tenebrio molitor larvae with parameters of body length, body weight gain, and mortality. The method used is an experimental method with a Completely Randomized Design (CRD). The study used 6 treatments with 2 replications. Garbage used is vegetable and fruit waste and chicken manure with each garbage given a dose of $12.5 \mathrm{mg} / \mathrm{larvae} /$ day, $25 \mathrm{mg} / \mathrm{larvae} /$ day, and $50 \mathrm{mg} / \mathrm{larvae} /$ day. The observed variables were the growth of Tenebrio molitor larvae with parameters of body length, body weight, and mortality (death). The results showed that the highest average body length and larval body weight gain were in chicken manure feed media at a dose of $25 \mathrm{mg} /$ larvae/day, which were $2.021 \mathrm{~cm}$ and 0.067 grams. The highest average mortality rate was in vegetable and fruit waste media at a dose of $50 \mathrm{mg} / \mathrm{larvae} /$ day with a percentage of $12.8 \%$.
\end{abstract}

Keywords: tegetable and fruit waste, chicken manure, growth, Tenebrio molitor larvae 


\section{PENDAHULUAN}

Sampah merupakan sisa aktivitas manusia setiap hari sehingga terdapat pengaruh antara jumlah penduduk dan pola konsumsi setiap orang terhadap volume, jenis, dan karakteristik sampah (Undang-Undang Republik Indonesia Nomor 18 Tahun 2008). Namun, jumlah sampah yang ada saat ini belum banyak dimanfaatkan oleh masyarakat serta pengelolaan maupun pengolahan sampah dari masyarakat masih kurang. Hal ini berdampak negatif pada kondisi lingkungan sekitar, seperti sungai dan laut menjadi tercemar bahkan berdampak pada kehidupan biota karena adanya pembuangan sampah ke sungai maupun laut, udara menjadi tercemar karena adanya aktivitas pembakaran sampah, dan sebagainya.

Sampah terbagi menjadi dua macam berdasarkan jenis atau zat kimia yang terkandung, yaitu sampah organik dan sampah anorganik. Sampah organik merupakan sampah yang dapat didegradasi oleh mikroba, seperti sampah yang berasal dari bahan hayati. Sampah anorganik merupakan sampah yang sulit didegradasi secara keseluruhan bahkan membutuhkan waktu yang lama untuk bisa diurai oleh mikroba maupun alam, seperti sampah plastik, sampah logam, dan sebagainya (Basriyanta, 2007).

Sampah organik memiliki volume lebih besar dibandingkan dengan sampah anorganik (Hariyanto, 2014). Hal ini dikarenakan sumber dari sampah organik banyak berasal dari rumah tangga, pasar, warung makan skala besar maupun kecil, dan sampah peternakan. Sampah organik yang tidak dilakukan pengelolaan dan pengolahan yang baik, seperti langsung dibuang ke selokan maupun ke sungai tanpa dilakukan pengolahan terlebih dahulu dapat menghambat aliran air, mengurangi kadar oksigen di dalam air, serta dapat menyebabkan pertumbuhan organisme yang merugikan.

Salah satu bentuk pengelolaan sampah organik adalah mengubah sampah organik menjadi sumber protein dengan memanfaatkan sampah organik sebagai media pakan untuk serangga yang dapat melakukan biokonversi sampah organik (Muhayyat dkk., 2016). Serangga akan mengkonsumsi sampah organik dan mengubah kandungan nutrisi dari sampah menjadi biomassa serangga (Fahmi, 2015).

Larva Tenebrio molitor merupakan salah satu serangga yang dapat dimanfaatkan dalam pengelolaan sampah organik sebagai media pakan larva (Tan dkk., 2018). Media pakan larva yang berasal dari sampah organik dapat dapat diperoleh dengan mudah dan murah. Larva juga memiliki pertambahan bobot yang tinggi dengan media pakan sampah organik (Hartiningsih \& Sari, 2014). Larva Tenebrio molitor juga dapat dimanfaatkan sebagai alternatif pakan ternak karena mengandung nutrisi yang tinggi (Kuntadi dkk., 2018). 
Tujuan dari penelitian ini adalah untuk mengetahui adanya pengaruh dari jenis sampah organik yang diberikan dengan dosis yang berbeda terhadap pertumbuhan larva Tenebrio molitor dengan parameter panjang tubuh, pertambahan berat tubuh, serta mortalitas. Rumusan masalah dalam penelitian ini adalah apakah terdapat pengaruh dari jenis sampah organik yang diberikan dengan dosis yang berbeda terhadap pertumbuhan larva Tenebrio molitor (ulat hongkong)?. Manfaatnya adalah mengurangi dampak negatif yang dapat ditimbulkan dari sampah organik dengan memanfaatkan sampah organik yang ada di lingkungan sekitar sebagai pakan larva Tenebrio molitor.

\section{METODE}

\section{Metode Penelitian}

Penelitian ini menggunakan metode penelitian eksperimen dengan model rancangan penelitian RAL (Rancangan Acak Lengkap) yang yang terdiri atas 6 perlakuan dengan masing-masing perlakuan dilakukan pengulangan sebanyak 2 kali. Perlakuan yang diberikan adalah dengan menggunakan dua macam sampah organik, yaitu sampah sayur dan buah serta kotoran ayam. Masing-masing jenis sampah organik diberikan dengan 3 dosis yang berbeda, yaitu 12,5mg/larva/hari, 25 mg/larva/hari, dan 50 mg/larva/hari (Supriyatna dan Putra, 2017). Penelitian dilakukan selama 14 hari.

\section{Prosedur Penelitian}

Persiapan Pakan

Sampah sayur dan buah terdiri atas pokchai, sawi putih, labu siam, bayam, tahu, tempe, kubis, wortel, terong, dan jambu. Sampah sayur dan buah diperoleh dari pasar, warung, dan rumah tangga. Sampah sayur dan buah yang akan diberikan dicacah terlebih dahulu kemudian dicampur dengan perbandingan 1:1:1:1:1:1:1:1:1:1. Sampah peternakan terdiri atas kotoran ayam yang diperoleh dari peternakan ayam skala rumah. Kotoran ayam yang akan diberikan sebagai pakan larva ditambahkan dengan air sebanyak 0,5 ml/gram. Sampah organik digunakan sebagai pakan larva Tenebrio molitor dan masing-masing pakan diberikan dengan dosis yang berbeda, yaitu 12,5 mg/larva/hari, $25 \mathrm{mg} / \mathrm{larva} / \mathrm{hari}$, serta $50 \mathrm{mg} / \mathrm{larva} / \mathrm{hari}$. Persiapan Larva

Penelitian ini menggunakan larva Tenebrio molitor sebanyak 500 ekor dengan umur 5 minggu (Tan dkk., 2018). Larva yang akan dilakukan pengukuran berat tubuh dengan menggunakan timbangan digital dan pengukuran panjang tubuh menggunakan jangka sorong 
(ketelitian 0,05 $\mathrm{mm}$ ) terlebih dahulu. Penimbangan dan pengukuran panjang tubuh dilakukan pada $10 \%$ dari jumlah larva, yaitu sebanyak 50 ekor.

Larva yang sudah dilakukan pengukuran dimasukkan ke dalam baskom yang sudah disediakan dengan ukuran diamater 14,9 cm dan tinggi 7,6 cm. Kemudian diberikan sampah organik dengan berat sesuai dengan dosis yang diberikan. Masing-masing sampah organik diberikan setiap hari.

\section{Variabel yang Diamati}

\section{Panjang Tubuh}

Pengukuran panjang tubuh larva dilakukan dengan menggunakan jangka sorong (ketelitian 0,05 mm) pada awal penelitian dan di akhir penelitian. Sampel diambil secara acak sebanyak 50 ekor atau 10\% dari total keseluruhan larva.

\section{Pertambahan Berat Tubuh}

Pengukuran berat tubuh dilakukan di awal dan di akhir penelitian. Pengukuran berat badan dilakukan dengan menggunakan timbangan digital. Sampel diambil secara acak sebanyak 50 ekor atau $10 \%$ dari total keseluruhan untuk diukur berat tubuh. Rumus yang digunakan adalah sebagai berikut:

Pertambahan Berat Tubuh (mg/larva)= (berat tubuh akhir-berat tubuh awal):jumlah larva

\section{Mortalitas}

Tingkat kematian dari larva yang ada di setiap perlakuan berbeda-beda dan dapat diketahui dengan menghitung jumlah larva yang masih hidup di akhir penelitian. Kemudian dimasukkan ke dalam rumus sebagai berikut:

$$
\text { Mortalitas }=(\text { jumlah larva yang mati : jumlah larva awal }) \times 100 \%
$$

\section{Analisis Data}

Data yang diperoleh dari kegiatan penelitian dikumpulkan kemudian dilakukan pengolahan dengan menggunakan Microsoft Excel. Data yang sudah diolah akan disajikan dengan menggunakan grafik dan dilakukan analisis.

\section{HASIL DAN PEMBAHASAN}

\section{Panjang dan Pertambahan Panjang Larva}

\section{Panjang Larva}

Panjang larva Tenebrio molitor yang diukur sebelum diberikan perlakuan memiliki ratarata panjang tubuh sekitar $1,149 \mathrm{~cm}$. Setelah diberikan perlakuan, rata-rata panjang tubuh larva pada masing-masing perlakuan yang akan diberikan memiliki kisaran antara 1,832- 
$2,021 \mathrm{~cm}$. Rata-rata pertambahan panjang tubuh berkisar antara 0,669-0,861 cm. Perbedaan dari kualitas media pakan yang diberikan (sampah sayur dan buah serta kotoran ayam) dapat menyebabkan adanya perbedaan rata-rata panjang tubuh dan pertambahan panjang tubuh larva (Purnamasari dkk., 2018).

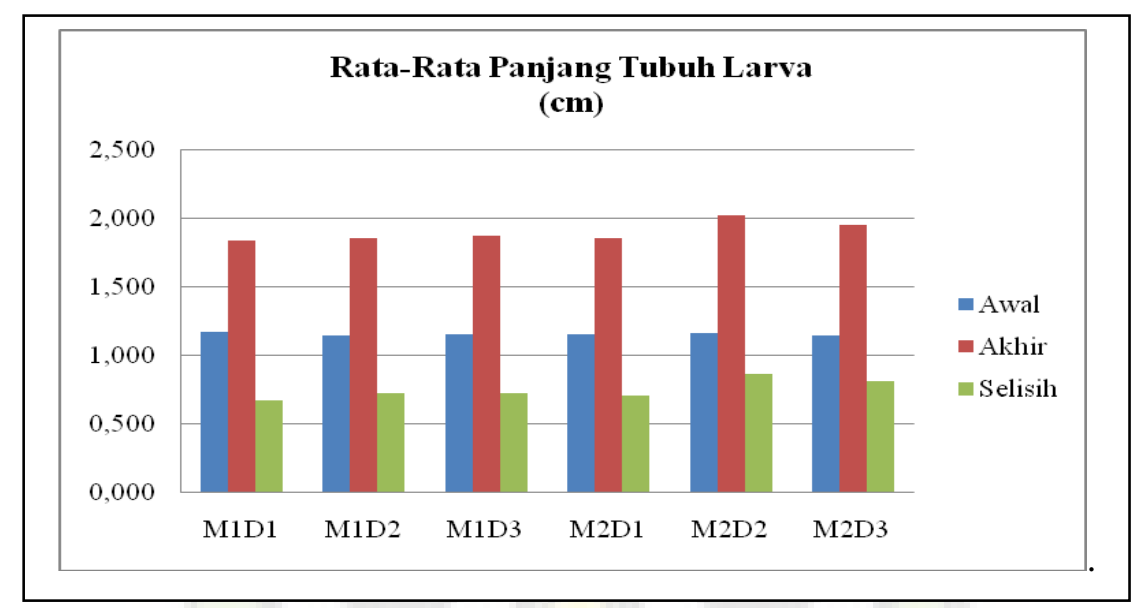

Gambar 1. Rata-Rata Panjang Tubuh Larva (cm/larva/14 hari)

Keterangan: M1D1=sampah sayur dan buah dosis 12,5 mg/larva/hari; M1D2=sampah sayur dan buah dosis $25 \mathrm{mg} / \mathrm{larva} / \mathrm{hari}$; M1D3=sampah sayur dan buah dosis 50 $\mathrm{mg} / \mathrm{larva} /$ hari; M2D1=kotoran ayam dosis 12,5 mg/larva/hari; M2D2=kotoran ayam dosis 25 $\mathrm{mg} / \mathrm{larva} / \mathrm{hari}$; M2D3=kotoran ayam dosis $50 \mathrm{mg} / \mathrm{larva} / \mathrm{hari}$.

Grafik Gambar 1 menunjukkan bahwa rata-rata panjang tubuh larva Tenebrio molitor yang paling tinggi adalah pada media kotoran ayam dengan dosis $25 \mathrm{mg} / \mathrm{larva} / \mathrm{hari}$ (M2D2) sebesar 2,021 cm. Selisih rata-rata panjang tubuh larva tertinggi juga terdapat pada media kotoran ayam dengan dosis $25 \mathrm{mg} /$ larva/hari sebesar $0,861 \mathrm{~cm}$.

Rata-rata panjang tubuh dan selisih panjang tubuh yang tinggi pada media M2D2 dibandingkan dengan larva pada media sampah yang lain dikarenakan adanya faktor yang mempengaruhi. Salah satu faktor yang mempengaruhi adalah adanya ketersediaan kandungan nutrisi yang cukup untuk larva Tenebrio molitor. Kandungan nutrisi tersebut dapat diduga berupa adanya sisa-sisa pakan ayam yang terbuang dan bercampur dengan kotoran ayam ataupun nutrisi yang terkandung di dalam kotoran ayam. Nutrisi yang diperoleh oleh larva dalam media M2D2 dapat digunakan untuk menambah panjang tubuh dengan membentuk jaringan tubuh masing-masing larva (Azizi, 2018). Faktor eksternal lain adalah suhu dan kelembaban lingkungan sekitar (Astuti dkk., 2017).

Rata-rata panjang tubuh dan pertambahan panjang tubuh larva Tenebrio molitor terendah terjadi pada media pakan berupa sampah sayur dan buah dengan dosis 12,5 mg/larva/hari 
(M1D1). Rata-rata panjang tubuh larva media M1D1 sebesar 1,832 $\mathrm{cm}$ dan pertambahan panjang larva sebesar $0,669 \mathrm{~cm}$. Hal ini diduga nutrisi dan jumlah pakan yang tersedia di dalam media M1D1 tidak mencukupi kebutuhan pertumbuhan dari keseluruhan larva yang ada. Hal ini berdampak pada pertambahan rata-rata panjang tubuh larva yang rendah.

\section{Berat Tubuh dan Pertambahan Berat Tubuh Larva}

Rata-rata berat tubuh larva Tenebrio molitor sebelum diberi perlakuan sebesar 0,014 gram. Setelah diberikan perlakuan, rata-rata tubuh larva pada media pakan yang diberikan memiliki kisaran antara 0,043-0,067 gram dengan pertambahan berat tubuh larva kisaran 0,030-0,053 gram. Hal ini menunjukkan terdapat perbedaan rata-rata berat tubuh larva dan rata-rata pertambahan berat tubuh di akhir penelitian. Perbedaan yang terjadi disebabkan karena adanya perbedaan kandungan nutrisi pada media pakan yang digunakan. Tingkat kandungan nutrisi dari media pakan yang diberikan dapat mempercepat ataupun menghambat pertumbuhan dan perkembangan larva (Katayane dkk., 2014).

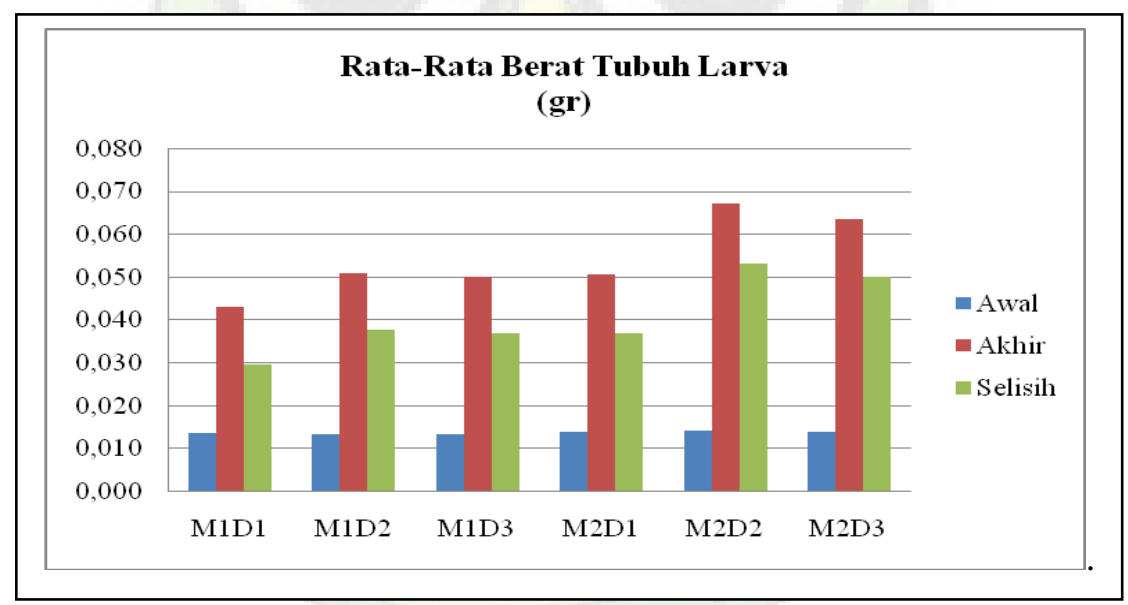

Gambar 2. Rata-Rata Berat Tubuh Larva (g/larva/14 hari)

Keterangan: M1D1=sampah sayur dan buah dosis 12,5 mg/larva/hari; M1D2= sampah sayur dan buah dosis $25 \mathrm{mg} /$ larva/hari; M1D3= sampah sayur dan buah dosis 50 $\mathrm{mg} / \mathrm{larva} / \mathrm{hari}$; M2D1= kotoran ayam dosis 12,5 mg/larva/hari; M2D2= kotoran ayam dosis $25 \mathrm{mg} / \mathrm{larva} / \mathrm{hari}$; M2D3= kotoran ayam dosis $50 \mathrm{mg} / \mathrm{larva} / \mathrm{hari}$.

Grafik Gambar 2 menunjukkan bahwa rata-rata berat tubuh dan pertambahan berat tubuh larva Tenebrio molitor paling tinggi terjadi pada media kotoran ayam dosis $25 \mathrm{mg} / \mathrm{larva} / \mathrm{hari}$ (M2D2) sebesar 0,067 gram dan 0,053 gram. Bobot larva yang besar dapat dipengaruhi oleh laju konsumsi larva terhadap media pakan dan ketersediaan nutrisi yang cukup pada media pakan (Purnamasari dkk., 2018). Selain itu, juga dapat dipengaruhi oleh kelembaban. Kelembaban yang rendah dapat memicu larva untuk mengkonsumsi media pakan lebih banyak (Hartiningsih \& Sari, 2014). Kotoran ayam mengandung protein dan zat gizi sehingga 
dapat berpengaruh pada rata-rata bobot tubuh dan pertambahan bobot tubuh larva (Katayane dkk., 2014) serta diduga terdapat sisa pakan ayam yang terbuang dan bercampur pada kotoran ayam.

Rata-rata berat tubuh larva dan pertambahan berat tubuh paling rendah terdapat pada media pakan berupa sayur dan buah dosis $12,5 \mathrm{mg} / \mathrm{larva} / \mathrm{hari}$, yaitu sebesar 0,043 gram dan 0,030 gram. Hal ini dikarenakan pada media pakan tidak dapat mencukupi kebutuhan nutrisi dari seluruh larva yang ada di media pakan tersebut sehingga dapat menghambat pertumbuhan larva Tenebrio molitor, terutama berat tubuh dan pertambahan berat tubuh dari larva.

\section{Tingkat Mortalitas Larva}

Rata-rata tingkat mortalitas (kematian) larva Tenebrio molitor berbeda di masing-masing media pakan yang digunakan. Tingkat mortalitas yang terjadi berkisar antara 2,4\%-12,8\% atau sekitar 12-64 ekor larva yang mati selama 14 hari diberi perlakuan. Perbedaan ini diduga disebabkan adanya perbedaan suhu dan kelembaban masing-masing media maupun nutrisi yang terkandung dalam media yang berpengaruh pada pertumbuhan maupun perkembangan (Katayane, 2014).

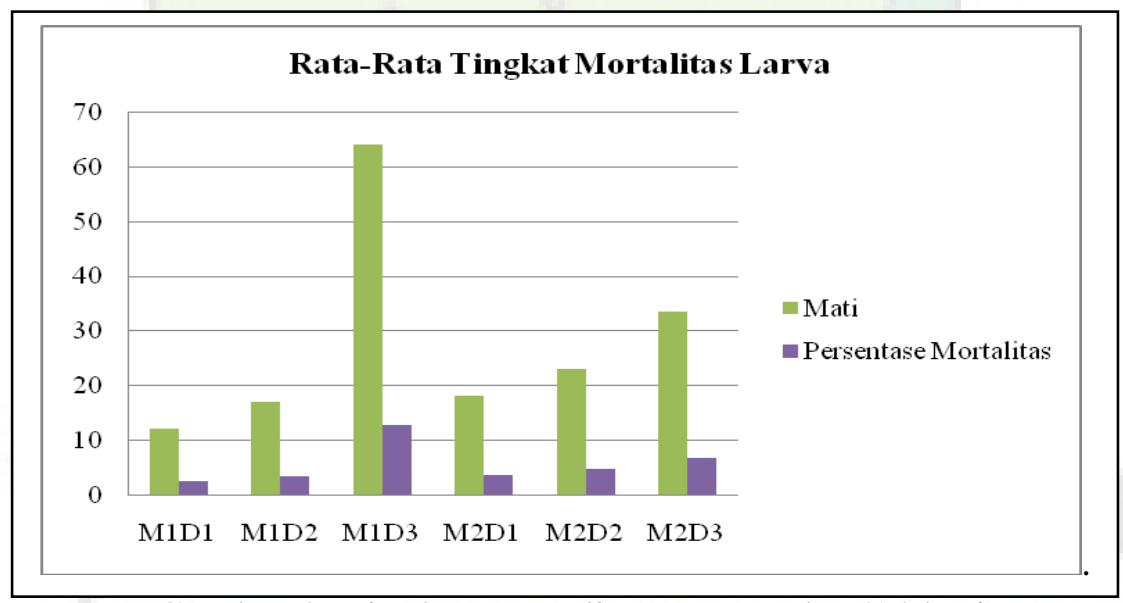

Gambar 3. Tingkat Mortalitas Larva (ekor/14 hari)

Keterangan: M1D1=sampah sayur dan buah dosis 12,5 mg/larva/hari; M1D2= sampah sayur dan buah dosis $25 \mathrm{mg} / \mathrm{larva} / \mathrm{hari}$; M1D3= sampah sayur dan buah dosis 50 $\mathrm{mg} / \mathrm{larva} / \mathrm{hari}$; M2D1= kotoran ayam dosis 12,5 mg/larva/hari; M2D2= kotoran ayam dosis $25 \mathrm{mg} / \mathrm{larva} / \mathrm{hari}$; M2D3= kotoran ayam dosis $50 \mathrm{mg} / \mathrm{larva} / \mathrm{hari}$.

Grafik Gambar 3 menunjukkan rata-rata tingkat mortalitas larva paling tinggi adalah pada media pakan berupa sampah sayur dan buah dengan dosis $50 \mathrm{mg} / \mathrm{larva} / \mathrm{hari}$ (M1D3). Hal ini diduga disebabkan adanya pembusukan pada media pakan. Pembusukan terjadi karena 
banyaknya jumlah kandungan air yang terkandung dalam media pakan sayur dan buah yang diberikan sesuai dosis sehingga media cepat mengalami pembusukan. Proses pembusukan sampah dimulai dari media pakan yang sudah lama menumpuk (bagian bawah). Hasil dari pembusukan sampah adalah adanya perubahan pada media pakan, yaitu media pakan cenderung berair pada bagian bawah dan mengakibatkan larva bergerak menuju ke permukaan media pakan. Banyaknya air yang terdapat dalam media pakan dapat menambah tingkat mortalitas dari larva.

Rata-rata tingkat mortalitas larva Tenebrio molitor paling rendah adalah pada media sampah sayur dan buah dosis 12,5 mg/larva/hari (M1D1), yaitu sebesar 2,4\% dari jumlah keseluruhan larva yang digunakan. Tingkat mortalitas larva yang rendah disebabkan karena jumlah kadar air yang terkandung dalam media M1D1 tidak terlalu banyak dibandingkan dengan jumlah kadar air pada media M1D3.

\section{SIMPULAN}

Kesimpulan yang diperoleh dari hasil penelitian tentang pemanfaatan sampah organik sebagai media pakan larva Tenebrio molitor (ulat hongkong) adalah rata-rata panjang tubuh larva dari jenis media pakan dan dosis yang diberikan paling tinggi adalah pada media pakan dari kotoran ayam dengan dosis sebesar $25 \mathrm{mg} / \mathrm{larva} / \mathrm{hari}$ sebesar 2,021 cm dan pertambahan panjang tubuh sebesar $0,861 \mathrm{~cm}$. Panjang tubuh larva terendah selama masa penelitian terjadi pada larva dengan media pakan berupa sayur dan buah dengan dosis 12,5 mg/larva/hari yaitu sebesar 1,832 cm dan memiliki pertambahan panjang tubuh sebesar 0,669 cm.

Rata-rata berat tubuh dan pertambahan berat tubuh larva paling besar adalah pada media pakan dari kotoran ayam dengan dosis sebesar $25 \mathrm{mg} / \mathrm{larva} / \mathrm{hari}$ (M2D2) sebesar 0,067 $\mathrm{g}$ dan 0,053 g. Rata-rata berat tubuh dan pertambahan berat tubuh paling rendah adalah pada larva dengan media sayur dan buah dengan dosis 12,5 mg/larva/hari sebesar 0,043 dan 0,030.

Rata-rata tingkat mortalitas (kematian) dari larva Tenebrio molitor adalah pada pakan sayur dan buah dengan dosis $50 \mathrm{mg} /$ larva/hari yaitu sebesar 12,8\% dan mortalitas yang terendah terjadi pada media pakan sayur dan buah dengan dosis 12,5 mg/larva/hari yaitu sebesar $2,4 \%$.

\section{REFERENSI}

Astuti, F.K., Iskandar, A., \& Fitasari, E. 2017. Peningkatan Produksi Ulat Hongkong di Peternak Rakyat Desa Patihan, Blitar Melalui Teknologi Modifikasi Ruang 
Menggunakan Exhoust dan Termometer Digital Otomatis. Jurnal Akses Pengabdian Indonesia, 1 (2): 39-48.

Azizi, Z. 2018. Penggunaan Berbagai Jenis Kotoran Ternak Terhadap Pertumbuhan dan Produksi Larva Hermetia illucens (Kajian Potensi Sebagai Pakan Unggas). Publikasi Ilmiah. Mataram: Program Studi Peternakan Universitas Mataram.

Basriyanta. 2007. Memanen Sampah. Yogyakarta: Penerbit Kanisius.

Fahmi, M.R. 2016. Optimalisasi Proses Biokonversi dengan Menggunakan Mini-Larva Hermetia illucens untuk Memenuhi Kebutuhan Pakan Ikan. Prosiding Seminar Nasional Masyarakat Biodiversitas Indonesia, 1 (1): 139-144.

Hapsari, D.G.P.L., Fuah, A.M., \& Endrawati, Y.C. 2018. Produktivitas Ulat Hongkong (Tenebrio molitor) Pada Media Pakan yang Berbeda. Jurnal Ilmu Produksi dan Teknologi Hasil Peternakan, 6 (2): 53-59.

Hariyanto. 2014. Pengelolaan Sampah di Kota Semarang untuk menuju Kota Bersih. Jurnal Geografi, 11 (2): 237-246.

Hartiningsih \& Sari, E.F. 2014. Peningkatan Bobot Panen Ulat Hongkong Akibat Aplikasi Limbah Sayur dan Buah Pada Media Pakan Berbeda. Buana Sains, 14 (1): 55-64.

Katayane, F.A., Bagau, B., Wolayan, F.R., \& Imbar, M.R. 2014. Produksi dan Kandungan Protein Maggot (Hermetia illucens) dengan Menggunakan Media Tumbuh Berbeda. Jurnal Zootek, (34): 27-36.

Kuntadi, Adalina, Y., \& Maharani, K.E. 2018. Nutritional Compositions of Six Edible Insects in Jawa. Journal of Forestry Research, 5 (1): 57-68.

Muhayyat, S.M., Yuliansyah, A.T., \& Prasetya, A. 2016. Pengaruh Jenis Limbah dan Rasio Umpan pada Biokonversi Limbah Domestik Menggunakan Larva Black Soldier Fly (Hermetia illucens). Jurnal Rekayasa Proses, 10 (1):23-29.

Purnamasari, D.K., Erwan, Syamsuhaidi, K.G.W., \& Nurmaya. 2018. Pertumbuhan dan Survival Rate Larva Tenebrio molitor yang Diberikan Media Pakan Berbeda. Jurnal Peternakan Sriwijaya, 7 (2): 17-23.

Supriyatna, A. \& Putra, R.E. 2017. Estimasi Pertumbuhan Larva Lalat Black Soldier (Hermetia illucens) dan Penggunaan Pakan Jerami Padi yang Difermentasi dengan Jamur P. chrysosporium. Jurnal Biodjati, 2 (2): 159-166, (Online), (http://journal.uinsgd.ac.id/index.php/biodjati/article/viewFile/1569/1243, diakses 22 Desember 2018).

Tan, S.W., Lai, K.S., \& Loh, Y. 2018. Effects of Food Wastes on Yellow Mealworm Tenebrio molitor Larva Nutritional Profiles and Growth Performances. Examines Marine Biology Oceanography, 2 (1): 1-6, (Online), (https://crimsonpublishers.com/eimbo/pdf/EIMBO.000530.pdf, diakses tanggal 25 Januari 2018).

Undang-Undang Republik Indonesia Nomor 18 Tahun 2008 tentang Pengelolaan Sampah 